\title{
Evaluation of Suya (Tsire) - An Intermediate Moisture Meat Product in Ogun State, Nigeria
}

\author{
E. S. Apata ${ }^{1}$, I. A. Kuku', O. C. Apata ${ }^{2}$ \& K. O. Adeyemi ${ }^{3}$ \\ ${ }^{1}$ Meat Science Laboratory, Department of Animal Production, Olabisi Onabanjo University, Yewa Campus, \\ Ayetoro, Ogun State, Nigeria \\ ${ }^{2}$ Department of Home and Hotel Management, Olabisi Onabanjo University, Yewa Campus, Ayetoro, Ogun State, \\ Nigeria \\ ${ }^{3}$ National Productivity Centre, Sokoto, Nigeria \\ Correspondence: E. S. Apata, Meat Science Laboratory, Department of Animal Production, Olabisi Onabanjo \\ University, Yewa Campus, P. M. B 0012, Ayetoro, Ogun State, Nigeria. E-mail: ebunoluapata2008@yahoo.com
}

Received: May 8, 2012 Accepted: November 13, 2012 Online Published: January 24, 2013

doi:10.5539/jfr.v2n1p87 URL: http://dx.doi.org/10.5539/jfr.v2n1p87

\begin{abstract}
A study was conducted to evaluate suya (tsire) an intermediate moisture meat product in Ogun State. Sixty suya sticks were used. Twelve suya sticks were prepared in the laboratory while 12 suya sticks were collected from each zone of the state namely: Yewa, Egba, Remo and Ijebu. They were analyzed for physical, chemical, microbiological and organoleptic characteristics. The results showed that there were significant $(\mathrm{P}<0.05)$ differences in physical properties of suya samples analyzed with suya from Yewa zone having the highest $(\mathrm{P}<$ $0.05)$ water holding capacity and suya prepared in the laboratory and those from Egba zone had the highest $(\mathrm{P}<$ $0.05)$ shear force, while the $\mathrm{pH}$ was least $(\mathrm{P}<0.05)$ in suya prepared from laboratory. Moisture content was least $(\mathrm{P}<0.05)$ in suya samples prepared in the laboratory and from Egba zone, while ash content was higher $(\mathrm{P}<0.05)$ in suya from Yewa, Remo and Ijebu Zones. Aerobic bacteria and coliform counts were least $(\mathrm{P}<0.05)$ in suya prepared in the laboratory and from Egba Zone, while lactic acid bacteria were higher $(\mathrm{P}<0.05)$ in suya prepared in the laboratory and from Egba Zone. The results revealed that suya samples prepared in the laboratory were accepted more $(\mathrm{P}<0.05)$ followed by those from Egba and Remo Zones. However, microbial loads observed on Suya (tsire) samples in this study were not as high as those reported by previous workers. Nonetheless, efforts should be made to educate meat and meat products (Suya) processors in Ogun State on the importance of hygiene and proper packaging and preservation to avoid contamination and spoilage of meat products during processing and sale.
\end{abstract}

Keywords: evaluation, Suya, microbial load, meat-product, organoleptic

\section{Introduction}

Meat plays an important role in human diet by contributing both macro and micro nutrients that are required for growth and good health maintenance. The rate of increase in per capita consumption of meat was found to be very high in developed countries when compared with developed nations. (Anjaneyulu et al., 2007). Meat is high in nutrients, but very prone to spoilage and to prevent this from occurring value addition to meat is essential (Anna et al., 2005). This involves processing and preservation of meat so as to prolong its shelf-life and improve its acceptability. (Eyas Ahmed et al., 2006). Processing aids in producing varieties and convenient meat products in order to meet various lifestyle requirements, while preservation aided by processing extend the shelf-life of meat and meat products (Sharma \& Kondaiah, 2005). The need for effective, cheap and simple preservative technique cannot be ignored and one of such is intermediate moisture food processing such as suya (tsire) (Omojola, 2008). It is a mass consumer fast food which is processed and sold along streets often under unhygienic conditions (Uzeh et al., 2006). Suya when being sold is usually packaged in old newspaper, also most of the stages for processing the product, the materials used, the handlers and the environment where it is processed and sold can serve as sources of contamination to the product (Uzeh et al., 2006). It has been reported (Omojola, 2008) that the meat and some of the ingredients used for processing suya can also serve as the product contaminant especially groundnut cake power. Pace (1975) and (Solberg et al., 1986) also reported that dangerous microbial contamination of delicatessen like suya occurs when the total aerobic and or enterobic (coliform) counts reach $10^{5} \mathrm{cfu} / \mathrm{g}$ and or lactic acid bacteria 
$10^{2} \mathrm{cfu} / \mathrm{g}$. This condition in turn can affect the aesthetics and other eating qualities of the meat product (Anjaneyulu et al., 2007). The objective of this study therefore, is to evaluate the physicochemical, microbial and organoleptic characteristics of suya (tsire) in Ogun State of Nigeria.

\section{Materials and Methods}

\subsection{Preparation of Suya Ingredients}

The spices used in preparing the ingredient were purchased from specialized spice market. They included ginger (Zingiber officinales), alligator pepper (Afromomum melegueta), black pepper (Piper guineense), red pepper (Capsicum fructescens). Other constituents of the ingredients were groundnut cake powder (Arachis hypogea) Salt (Sodium chloride) and seasoning (Monosodium glutamate). The spices and other ingredient constituents were milled individually and mixed together in a specific proportion as described by Igene and Ekanen (1985) since the ingredients used by the processors of suya in Ogun State are similar to that used by the authors as shown in (Table $1)$.

Table 1. Composition of Suya ingredient

\begin{tabular}{lll}
\hline Ingredient Constituents & Proportion by Weight (g) & Percent Proportion in Mixture (\%) \\
\hline Groundnut Cake Powder & 450 & 63.83 \\
Ginger & 60 & 8.51 \\
Alligator Pepper & 10 & 1.42 \\
Black Pepper & 10 & 1.42 \\
Red Pepper & 60 & 8.51 \\
Salt & 70 & 9.93 \\
Monosodium Glutamate & 45 & 6.38 \\
Total & 705 & 100.00 \\
\hline
\end{tabular}

Source: Igene and Ekanem (1985).

\subsection{Processing of Suya}

Twelve sticks of suya were prepared in the Meat Science Laboratory, Department of Animal Production, Olabisi Onabanjo University, Ayetoro Campus to serve as the control $(\mathrm{O})$ using beef muscle from the leg cut as described by (Omojola, 2008). Meat samples were sliced into thin sheets and were inserted onto the weighed suya sticks. The ingredient was spread on a flat tray and each stick of meat was pressed on the ingredient to be properly soaked into the meat. The sticks of meat were labeled, about $5-10 \mathrm{ml}$ of groundnut oil was sprinkled on each meat stick before roasting.

\subsection{Roasting of Suya}

Labeled sticked meats were arranged round a glowing smokeless fire made from charcoal. The sticked meats were allowed to stay on the fire for $20 \mathrm{~min}$ with the distance of $22-23 \mathrm{~cm}$ from the centre of fire and intermittent turning of the product. Additional groundnut oil was sprinkled on the meat while roasting continued (Omojola, 2008). All necessary hygienic precausions were observed in the laboratory.

\subsection{Collection of Suya from Four Zones of Ogun State}

Fourty eight Suya (tsire) samples were purchased from three towns that are popular in processing suya in each of the four geo-political zones of Ogun State. Suya samples from each zone represented a treatment, thus five treatments of Suya samples (12 samples from each zone and 12 samples prepared in the laboratory equals 60 sticks of Suya). The suya samples were evaluated as follows.

0 (control) $=$ Suya samples processed in the laboratory

$1=$ Suya samples collected from Yewa Zone

2 = Suya samples collected from Egba Zone

3 = Suya samples collected from Remo Zone

4 = Suya samples collected from Ijebu Zone 


\subsection{Determination of Chemical Composition of Suya}

This was carried out as described by (AOAC, 2000). Moisture content was determined by drying the suya sample $(2 \mathrm{~g})$ from each stick in an oven at $\left(100-105^{\circ} \mathrm{C}\right)$ until constant weight was achieved. Crude protein of suya samples was obtained using Kjeldahl methods which included digestion, distillation and titration of the distillates. The values of crude protein were derived by converting nitrogen (N\%) content of the distillates with a constant (6.25) thus, crude protein was obtained as $(6.25 \mathrm{xN} \%)$. Crude fat of suya was determined with soxhlet extraction method using petroleum ether. Suya samples were dried in an oven for 4 hours and fat was extracted. Ash content of suya was determined by igniting the suya samples in a Muffle furnace at $\left(550-600^{\circ} \mathrm{C}\right)$ for 24 hours until ashes were formed.

\subsection{Determination of Lipid Oxidation of Suya}

Lipid oxidation of Suya samples was determined using the modified peroxide value (mPV) method described by (AOAC, 2000). $50 \mathrm{~g}$ of Suya samples from each treatment were ground in a blender (plate $5 \mathrm{~mm}$ ) model 242 NAKAI, JAPAN for 20-30sec. and extracted with $30 \mathrm{ml}$ of ice cold (3:2 V/V) acetic acid: chloroform. $0.5 \mathrm{ml}$ of saturated $\mathrm{k} 1$ was added and mixed thoroughly by adding $30 \mathrm{ml}$ of distilled water. The mixture was allowed to stand for 5-10min at room temperature. The mixture was titrated with $0.01 \mathrm{M} \mathrm{Na}_{2} \mathrm{~S}_{2} \mathrm{O}_{3}$ gradually with vigorous shaking. $0.5 \mathrm{ml}$ starch indicator $(1 \%$ starch +0.3 chloroform $)$ was added. The sample mixture was vigorously swirled and was allowed to stand for an additional $10 \mathrm{~min}$. The end point of the titration was established when the colour of the upper aqueous layer disappeared. The modified peroxide value (mPV) of Suya samples was calculated using the following formula:

$$
\mathrm{mPV}=\frac{(S)(N)(1000)}{W}
$$

Where $\mathrm{mPV}=$ Modified Peroxide Value

$$
\begin{aligned}
& \mathrm{S}=\mathrm{M} 1 \text { of } \mathrm{Na}_{2} \mathrm{~S}_{2} \mathrm{O}_{3} \\
& \mathrm{~N}=\text { Normally of } \mathrm{Na}_{2} \mathrm{~S}_{2} \mathrm{O}_{3} \\
& \mathrm{~W}=\text { Weight of Suya samples (g of fat) }
\end{aligned}
$$

\subsection{Measurement of Shear Force of Suya}

Suya sample, $3.30 \mathrm{~cm}$ in diameter were sheared at three locations with Warner-Bratzler V-notch blade shearing instrument following the procedures described by Honikel (1998).

\subsection{Measurement of Water Holding Capacity (WHC) of Suya}

This was determined with press method according to Suzuki et al. (1991). An approximately 1g of Suya sample was placed between two $9 \mathrm{~cm}$ whatman No 1 filter papers (model C, Caver Inc, Wabash, U. S. A). The sandwish was pressed between two 10.2 × 10.2 plexiglasses for 1 minutes using a vice. Pressed suya samples were oven dried at $105^{\circ} \mathrm{C}$ for 24 hours and their moisture contents determined. Amount of water released from Suya samples was measured indirectly by measuring the area of filter paper wetted relative to the area of pressed suya samples. Water holding capacity of Suya samples was calculated thus:

$$
\mathrm{WHC}=\frac{100-(\mathrm{Aw}-\mathrm{As}) \times 9.47}{\mathrm{Ws} \times \mathrm{Mc}} \times 100
$$

Where Aw $=$ Area of water released from Suya Samples $\left(\mathrm{cm}^{2}\right)$

$$
\begin{gathered}
\text { As }=\text { Area of Suya Sample }\left(\mathrm{cm}^{2}\right) \\
\text { Ws }=\text { Weight of Suya Samples }(\mathrm{g}) \\
\mathrm{Mc}=\text { Moisture Content of Suya Samples (\%) } \\
9.47=\text { Constant Factor } \\
2.9 \text { Determination of Microbial Load of Suya }
\end{gathered}
$$

\subsection{Determination of Microbial Load of Suya}

This was carried out following the procedures of (APHA, 1992), (ICMSF 1986) and (AOAC, 2000). Suya samples from each treatment $(10 \mathrm{~g})$ were blended with $90 \mathrm{ml}$ of $0.1 \%(\mathrm{~W} / \mathrm{V})$ peptone water for $60 \mathrm{sec}$. with a blender of (plate $5 \mathrm{~mm}$ ) model 242 NAKAI, JAPAN. Additional dilutions were made in $0.1 \%$ peptone water (W/V). Thereafter, $1 \mathrm{ml}$ of undiluted homogenate of suya samples was spread on duplicate petriplates. Bacteria numbers were determined from plates bearing colonies. Counts were obtained as follows: AEROBIC plate counts on plate 
count Agar (DIFCO, USA) incubated at $32^{\circ} \mathrm{C}$ for 48hours; ENTEROBACTERIACEAE (Coliform) on Violet Red Bile Glucose Agar (DIFCO, USA) overlaid with the same medium and incubated at $37^{\circ} \mathrm{C}$ for 24 hours, while LACTIC ACID BACTERIA (LAB) were on Lactobacilli; MRS Broth (DIFCO, USA), Bacto Agar (DIFCO, USA) and glacial acetic acid (Pancrease) incubated at $32^{\circ} \mathrm{C}$ for 48 hours. Colony forming units were counted and were expressed in $\log _{10} \mathrm{cfu} / \mathrm{g}$ of samples.

\subsection{Sensory Evaluation of Suya}

This was conducted according to the procedures of (AMSA, 1995). A 10-member semi-trained taste panel was used. The panelists were supplied unsalted biscuits and water for use in between the treatments suya samples. Suya samples evaluated were coded and presented sequentially to the panelists on a clean saucer and were evaluated independently of each other. The panelists rated the suya samples on a 9-point hedonic scale on which 1=dislike extremely and $9=$ like extremely for colour, aroma, flavour, tenderness, juiciness, texture and overall-acceptability, where higher values indicated higher preference for suya from each treatment.

\subsection{Experimental Design and Statistical Analysis}

Completely randomized design (CRD) was used for this study. Data obtained from this study were analysed with (SAS, 2002), while the means were separated using Duncan multiple Range test of the same software.

\section{Results and Discussion}

The results of chemical composition of Suya ingredients prepared in the laboratory and those collected from Suya processors in each zone are presented in (Table 2).

The results showed that there was no significant $(\mathrm{P}>0.05)$ difference in the chemical composition of all the ingredients. This result confirmed the fact that almost all the Suya processors in Ogun State like their counterparts in the Northern part of Nigeria use similar ingredient (Igene \& Ekanem, 1985). Table 3 shows the results of mean physicochemical composition of Suya. There were significant $(\mathrm{P}<0.05)$ differences in all the variables except in fat, crude protein and lipid oxidation of Suya samples. Water Holding Capacity (WHC) (35.93\%) was highest (P< $0.05)$ in Suya sample from Yewa Zone and least $(\mathrm{P}<0.05)$, in suya samples prepared in the laboratory $(24.52 \%)$. Shear force values were higher $(\mathrm{P}<0.05)$ in suya prepared in the laboratory $\left(6.87 \mathrm{~kg} / \mathrm{cm}^{3}\right)$ and those collected from Egba Zone $\left(6.85 \mathrm{~kg} / \mathrm{cm}^{3}\right)$ and least $(\mathrm{P}<0.05)$ in suya samples from Yewa zone $\left(4.21 \mathrm{~kg} / \mathrm{cm}^{3}\right)$. The $\mathrm{pH}$ of Suya samples prepared in the laboratory $(5.93)$ was significantly lower $(\mathrm{P}<0.05)$ than in Suya samples from the four zones. Moisture contents of Suya samples from Yewa, Remo and Ijebu Zones were higher $(\mathrm{P}<0.05)$ than moisture content of Suya samples prepared in the laboratory and Egba Zone.

The results of the mean microbial load of Suya samples are presented in (Table 4). The results showed that there were significant $(\mathrm{P}<0.05)$ differences in the microbial loads of Suya samples. Aerobic bacteria and coliform were higher $(\mathrm{P}<0.05)$ in Suya from Yewa, Remo and Ijebu Zones and lower $(\mathrm{P}<0.05)$ in Suya prepared in the laboratory and from Egba Zone while Lactic Acid Bacteria $(\mathrm{LAB})$ were higher $(\mathrm{P}<0.05)$ in Suya prepared in laboratory $\left(1.25 \log _{10} / \mathrm{cfu} / \mathrm{g}\right)$ and Egba zone $\left(1.03 \log _{10} \mathrm{cfu} / \mathrm{g}\right)$ and lower $(\mathrm{P}<0.05)$ in Suya from Yewa, Remo and Ijebu zones.

Table 5 showed the results of mean organoleptic properties of Suya samples. The results indicated that there were significant $(\mathrm{P}<0.05)$ differences in organoleptic properties of Suya samples. Suya colour and flavour were higher $(\mathrm{P}<0.05)$ in Suya samples prepared in the laboratory, followed by those samples from Egba Zones and least $(\mathrm{P}<$ $0.05)$ in Suya samples from Yewa and Ijebu Zones. Suya samples from Yewa was adjudged the most $(\mathrm{P}<0.05)$ tender, followed by those from laboratory and other zones while Suya samples from Yewa and Ijebu Zones were rated the most $(\mathrm{P}<0.05)$ juicier, followed by those from Egba and Remo Zones and least $(\mathrm{P}<0.05)$ in Suya prepared in the laboratory. Suya texture was rated higher $(\mathrm{P}<0.05)$ in samples from the laboratory, Egba and Remo Zones, followed by that of Suya from Ijebu and least $(\mathrm{P}<0.05)$ in suya samples from Yewa Zone. The results revealed further that Suya samples prepared in the laboratory were accepted mostly $(\mathrm{P}<0.05)$. Those from Egba and Remo Zones were accepted the same $(\mathrm{P}>0.05)$, while those from Yewa zone were least $(\mathrm{P}<0.05)$ accepted. Water holding capacity and moisture content of Suya samples prepared in the laboratory and Egba Zone were not as high as they were in Suya samples from other zones, this could be responsible for higher shear force values of Suya samples from laboratory and Egba zone. Aduku and Olukosi (2000) reported that when moisture and water binding capacity of meat or meat product are lower Warner-Bratzler value of the meat or meat product is raised as observed in this study. Also, crude fibre was numerically high in Suya samples from Yewa, Remo and Ijebu Zones; this could be responsible for higher ash contents obtained in Suya samples from these zones. Crude protein was higher in Suya Samples prepared in the laboratory and those from Egba Zone. Crude fibre is normally not analyzed for in meat as it contains little or no fibre, whereas, it was observed to be considerably high in this 
meat product (suya) as a result of high level of fibre in some of the constituents of the ingredient used in preparing the meat products whose source was from plants. Similar result was reported by Omojola (2008). This could be due to the fact that meat used for Suya was able to absorb more Suya ingredient which could have added part of its protein content to the meat which was obtained in Suya samples (Omojola et al., 2004), as some of the ingredient constituents are rich in protein particularly groundnut cake which had highest proportion in the ingredient.

Microbial load was lower in Suya samples prepared in the laboratory and from Egba Zone probably due to lower moisture contents of Suya samples, but LAB was higher in Suya Samples from the laboratory and Egba Zones which might have aided in preserving the Suya samples, as aerobic bacteria could not thrive well in acidic medium, the number could have been reduced which might have raised the number of lactic acid bacteria which was not as destructive as the former species of microbes (Apata, 2010). The lower percentage moisture content and $\mathrm{pH}$ in Suya Samples prepared in the laboratory and those from Egba Zone might be responsible for lower lipid oxidation and microbial loads in Suya Samples from the laboratory and Egba zone. Also, higher LAB in Suya prepared from Laboratory might be responsible for higher and better colour, flavour, texture and overall acceptability of Suya, followed by those collected from Egba Zone. The results of microbial load of Suya samples also revealed the level of hygiene of the meat and ingredient used in preparing the Suya as well as that of environment and Suya processors (Uzeh et al., 2006). Lower acceptability score for Suya samples from Yewa Zone could be due to higher tenderness, juiciness, moisture, WHC, as well as reduced colour and flavour, probably due to microbial activities in Suya samples. It was reported (Anjaneyulu et al., 2007) that most consumer's adjudge meat and meat products based first on colour and then flavour, while (Okubanjo, 1990) reported that most citizens of developing countries like Nigeria prefer less tender meat or meat product probably for longer chewability.

Table 2. Chemical analysis of ingredients used for Suya from laboratory and treatment zones

\begin{tabular}{lllllll}
\hline & \multicolumn{7}{c}{ Zones } \\
\cline { 2 - 7 } Variable & $\mathbf{0}$ & $\mathbf{1}$ & $\mathbf{2}$ & $\mathbf{3}$ & $\mathbf{4}$ & SEM \\
\hline Moisture Content (\%) & 10.40 & 10.82 & 10.60 & 10.71 & 10.80 & 0.38 \\
Crude Protein (\%) & 7.00 & 6.55 & 6.87 & 6.62 & 6.57 & 0.15 \\
Ether Extract (\%) & 9.50 & 8.00 & 8.70 & 8.55 & 8.40 & 0.11 \\
Ash (\%) & 5.45 & 6.68 & 5.52 & 6.61 & 6.65 & 0.13 \\
Crude Fiber (\%) & 6.70 & 6.60 & 6.67 & 6.65 & 6.52 & 0.09 \\
pH & 5.35 & 5.47 & 5.40 & 5.45 & 5.45 & 0.20 \\
\hline
\end{tabular}

* No significant difference in the treatment means $(\mathrm{P}>0.05)$.

Table 3. Physicochemical composition of Suya samples

\begin{tabular}{lllllll}
\hline & \multicolumn{7}{c}{ Zones } \\
\cline { 2 - 7 } Variable & $\mathbf{0}$ & $\mathbf{1}$ & $\mathbf{2}$ & $\mathbf{3}$ & $\mathbf{4}$ & SEM \\
\hline Water Holding Capacity (\%) & $24.52^{\mathrm{e}}$ & $35.93^{\mathrm{a}}$ & $26.87^{\mathrm{d}}$ & $31.93^{\mathrm{c}}$ & $34.24^{\mathrm{b}}$ & 1.33 \\
Shear Force (kg/cm $\left.{ }^{3}\right)$ & $6.87^{\mathrm{a}}$ & $4.21^{\mathrm{c}}$ & $6.85^{\mathrm{a}}$ & $5.32^{\mathrm{b}}$ & $5.43^{\mathrm{b}}$ & 0.03 \\
$\mathrm{pH}$ & $5.93^{\mathrm{b}}$ & $6.82^{\mathrm{a}}$ & $6.16^{\mathrm{a}}$ & $6.20^{\mathrm{a}}$ & $6.40^{\mathrm{a}}$ & 0.08 \\
Moisture (\%) & $34.20^{\mathrm{b}}$ & $36.05^{\mathrm{a}}$ & $34.27^{\mathrm{b}}$ & $35.67^{\mathrm{a}}$ & $35.78^{\mathrm{a}}$ & 1.24 \\
Crude protein (\%) & $39.61^{\mathrm{a}}$ & $38.20^{\mathrm{b}}$ & $39.53^{\mathrm{a}}$ & $38.52^{\mathrm{b}}$ & $38.24^{\mathrm{b}}$ & 1.27 \\
Fat (\%) & 13.48 & 12.60 & 13.37 & 13.35 & 13.05 & 0.13 \\
Ash (\%) & $6.60^{\mathrm{b}}$ & $8.00^{\mathrm{a}}$ & $6.93^{\mathrm{b}}$ & $7.45^{\mathrm{a}}$ & $7.59^{\mathrm{a}}$ & 0.19 \\
Crude Fiber (\%) & 1.01 & 1.36 & 1.20 & 1.30 & 1.34 & 0.02 \\
Lipid Oxidation (meq/kg/fat) & $0.50^{\mathrm{c}}$ & $0.78^{\mathrm{a}}$ & $0.63^{\mathrm{b}}$ & $0.67^{\mathrm{b}}$ & $0.77^{\mathrm{a}}$ & 0.08 \\
\hline
\end{tabular}

abcde: Means in the same row with different superscripts are statistically significant $(\mathrm{P}<0.05)$. 
Table 4. Microbial load of Suya samples $\left(\log _{10} \mathrm{cfu} / \mathrm{g}\right)$

\begin{tabular}{lllllll}
\hline & \multicolumn{7}{c}{ Zones } \\
\cline { 2 - 7 } Variable & $\mathbf{0}$ & $\mathbf{1}$ & $\mathbf{2}$ & $\mathbf{3}$ & $\mathbf{4}$ & SEM \\
\hline Aerobic bacteria & $0.90^{\mathrm{b}}$ & $1.99^{\mathrm{a}}$ & $0.97^{\mathrm{b}}$ & $1.79^{\mathrm{a}}$ & $1.86^{\mathrm{a}}$ & 0.13 \\
Coliform & $0.41^{\mathrm{b}}$ & $1.69^{\mathrm{a}}$ & $0.46^{\mathrm{b}}$ & $1.55^{\mathrm{a}}$ & $1.61^{\mathrm{a}}$ & 0.68 \\
Lactic Acid Bacteria & $1.25^{\mathrm{a}}$ & $0.53^{\mathrm{c}}$ & $1.03^{\mathrm{b}}$ & $0.68^{\mathrm{c}}$ & $0.67^{\mathrm{c}}$ & 0.06 \\
\hline
\end{tabular}

$a b c:$ Means in the same row with different superscripts are statistically significant different $(\mathrm{P}<0.05)$.

Table 5. Mean organoleptic properties of Suya samples

\begin{tabular}{lllllll}
\hline \multirow{2}{*}{ Variable } & \multicolumn{7}{c}{ Zones } \\
\hline Colour & $\mathbf{0}$ & $\mathbf{1}$ & $\mathbf{2}$ & $\mathbf{3}$ & $\mathbf{4}$ & SEM \\
Flavour & $7.64^{\mathrm{a}}$ & $4.02^{\mathrm{d}}$ & $6.51^{\mathrm{b}}$ & $5.31^{\mathrm{c}}$ & $4.65^{\mathrm{d}}$ & 0.42 \\
Tenderness & $7.32^{\mathrm{a}}$ & $4.24^{\mathrm{d}}$ & $6.42^{\mathrm{b}}$ & $5.27^{\mathrm{c}}$ & $4.10^{\mathrm{d}}$ & 0.12 \\
Juiciness & $5.72^{\mathrm{b}}$ & $7.50^{\mathrm{a}}$ & $5.81^{\mathrm{b}}$ & $6.00^{\mathrm{b}}$ & $5.91^{\mathrm{b}}$ & 0.18 \\
Texture & $4.91^{\mathrm{c}}$ & $7.35^{\mathrm{a}}$ & $5.08^{\mathrm{b}}$ & $5.33^{\mathrm{b}}$ & $7.23^{\mathrm{a}}$ & 0.16 \\
Overall Acceptability & $7.26^{\mathrm{a}}$ & $4.51^{\mathrm{c}}$ & $7.10^{\mathrm{a}}$ & $7.08^{\mathrm{a}}$ & $5.71^{\mathrm{b}}$ & 0.31 \\
\hline
\end{tabular}

abcd: Means in the same row with different superscripts are statistically significant $(\mathrm{P}<0.05)$.

\section{Conclusion}

The findings from this study revealed that Suya Samples prepared in the laboratory was better followed by those collected from Egba, Remo, Ijebu and Yewa Zones respectively. It is also evident from this study that the microbial loads of Suya samples were not as high as those reported by previous workers, as spoilage was minimal. However, efforts should be geared towards educating meat and meat especially suya processors in Ogun State on the importance of hygiene and proper packaging and preservation, since microbial contamination due to improper preservation could lead to complete spoilage of suya product and subsequent reduction of its eating qualities and overall acceptability.

\section{References}

Aduku, A. O., \& Olukosi, J. O. (2000). Animal Products Processing and Handling in the Tropics (pp. 120-125). Living Book Series, G. U. Publications, Abuja, Nigeria.

AMSA. (1995). Research Guidelines for Cookery, Sensory evaluation and Instrumental measurement of fresh meat. National Livestock and Meat Board, Chicago, IL, USA. Retrieved from http://www.meat science.org

Anjaneyulu, A. S. R., Thomas, R., \& Kondaiah. (2007). Technologies for Value Added Buffalo meat products-A Review. Ame J. Food Tech., 2(3), 104-114. http://dx.doi.org/10.3923/ajft.2007.104.114

Anna, A. M., Lackshmannan, V., Mendiratta, S. K., Anjaneyulu, A. S. R., \& Bisht, G. S. (2005). Development and quality characteristics of extruded tripe snack from buffalo rumen meat and corn flour. J. Food Sci. Technol., 42, 263-267.

Apata, E. S. (2010). Evaluation of Lipid Oxidation and Microbial Load in Suya as affected by Post-mortem Processing and Preservation Time. Journal of Agric. Forestry and the Social Sciences, 8(2), 195-202.

APHA. (1992). Compendium of method for the microbiological examination of foods, 3rd edn Ame. Public Health Ass. In C. Vanderzant, \& D. F. Splitsloesser (Eds.). Michigan, USA. Retrieved from http://www.apha.org

Eyas Ahmed, M., Anjaneyulu, A. S. R., Thomas, R., \& Kondaiah, N. (2006). Effect of enrobing on the quality and shelf-life of buffalo meat cutlets under frozen storage. J. Muscle Foods.

Honikel, J. L. (1998). Reference Methods for the assessment of physical characteristics of meat. Meat Sci., 49, 447-457. http://dx.doi.org/10.1016/S0309-1740(98)00034-5 
ICMSF. (1986). Micro organisms in food 2. Sampling for Microbiological Analysis. Principles and Specific Applications (2nd ed). Canada: University of Toronto Press. Retrieved from http://www.cifst.org

Igene, J. O., \& Ekanem, E. O. (1985). Effect of processing methods on the nutritional and sensory characteristics of tsire - suya meat product. Nig. J. Appl. Sci., 3(1), 1-20.

Okubanjo, A. O. (1990). Meat for the Nigerian Millions. Faculty Lecture Series, Faculty of Agriculture and Forestry, University of Ibadan, Nigeria. No. 3.

Omojola, A. B. (2008). Yield and Organoleptic Characteristics of Suya (an intermediate moisture meat) prepared from three different muscles of a matured bull. Afr. J. Biotech, 7(13), 2254-2257.

Pace, P. J. (1975). Bacteriological quality of delicatessen foods are standard needed? J. Milk and Food Technol., $38,347-353$.

SAS. (2002). Statistical Analysis System. SAS Stat. Version 9 SAS Institute Inc. Garry, NC, USA.

Sharma, B. D., \& Kondaiah, N. (2005). Development of Buffalo meat samoa and evaluation of its storage in low vacuum Family Park under frozen condition. J. Vet. Pub. Health, 3, 59-62.

Solberg, M., Miskinuri, D. K., Martin, B. A., Page G., Golderer, S., \& Libfield, M. (1986). What do microbiological indicator tests tell us about safety of foods? Food Pro. Dev., 10, 27-30.

Suzuki, A., Koima, N., \& Nkeuchi, Y. (1991). Carcass Composition and meat quality of Chinese pure bred and $\begin{array}{llllll}\text { European } \mathrm{X} \text { Chinese Cross bred pigs. Meat } & \text { 31-41. }\end{array}$ http://dx.doi.org/10.1016/0309-1740(91)90021-H

Uzeh, R. E., Ohenhen, R. E., \& Adeniji, O. O. (2006). Bacterial Contamination of Tsire-Suya a Nigerian Meat Product. Pak. J. Nutri., 5(5), 458-460. http://dx.doi.org/10.3923/pjn.2006.458.460 